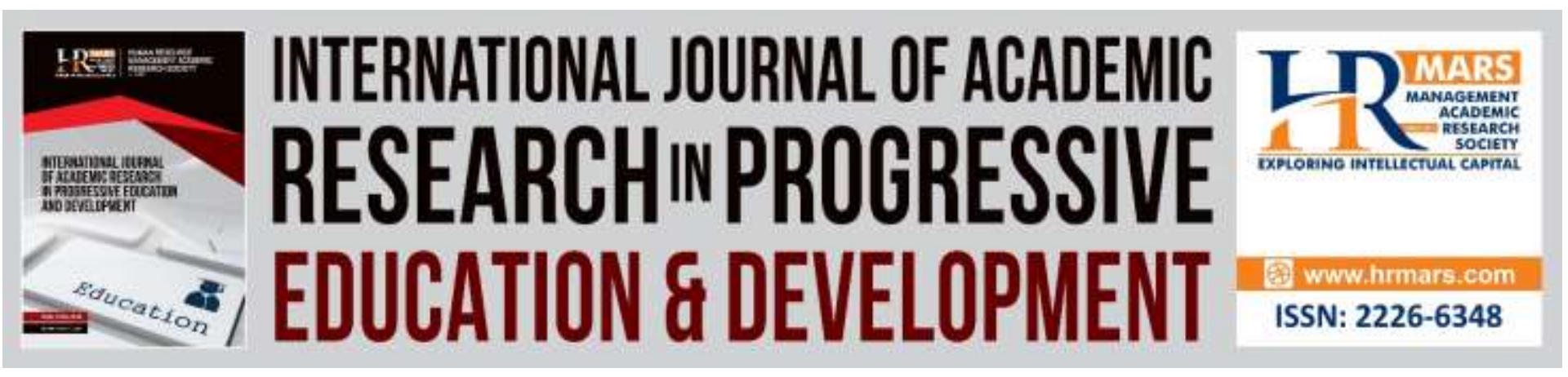

\title{
The Effectiveness of Bar Model to Enhance HOTs in Mathematics for Year 4 Pupils
}

\author{
Ragu Ramasamy \& Marzita Puteh
}

To Link this Article: http://dx.doi.org/10.6007/IJARPED/v8-i2/5695

DOI: $10.6007 /$ IJARPED/v8-i2/5695

Received: 29 March 2019, Revised: 19 April 2019, Accepted: 30 April 2019

Published Online: 06 May 2019

In-Text Citation: (Ramasamy \& Puteh, 2019)

To Cite this Article: Ramasamy, R., \& Puteh, M. (2019). The Effectiveness of Bar Model to Enhance HOTs in Mathematics for Year 4 Pupils. International Journal of Academic Research in Progressive Education and Development, 8(2), 200-204.

\section{Copyright: (C) 2019 The Author(s)}

Published by Human Resource Management Academic Research Society (www.hrmars.com)

This article is published under the Creative Commons Attribution (CC BY 4.0) license. Anyone may reproduce, distribute, translate and create derivative works of this article (for both commercial and non-commercial purposes), subject to full attribution to the original publication and authors. The full terms of this license may be seen

at: http://creativecommons.org/licences/by/4.0/legalcode

Vol. 8(2) 2019, Pg. 200 - 204

http://hrmars.com/index.php/pages/detail/IJARPED

JOURNAL HOMEPAGE

Full Terms \& Conditions of access and use can be found at http://hrmars.com/index.php/pages/detail/publication-ethics 


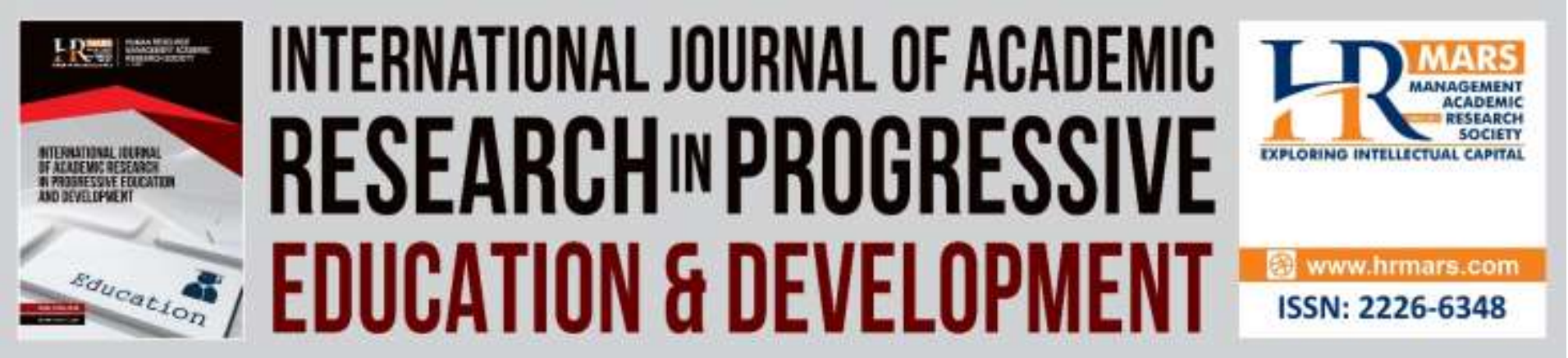

\title{
The Effectiveness of Bar Model to Enhance HOTs in Mathematics for Year 4 Pupils
}

\author{
Ragu Ramasamy \& Marzita Puteh \\ Faculty of Science \& Mathematics, UPSI, Malaysia
}

\begin{abstract}
This study aims to evaluate the effectiveness of using Bar Model in Mathematics problem solving questions involving Higher Order Thinking Skills (HOTs). This study involved 37 pupils from Year 4 class at SK Bukit Bandaraya. This study focusses on to examine the effectiveness using Bar Model by converting the HOTs problem solving questions to visual by drawing bar model. This is a quasiexperimental research and the effectiveness of this method will be analyse through the findings from pre-test and post-test. Discussion of the findings of this study is based on pupil's per-test and post-test. The results of this study analysed by using SPSS version 22 for pre-test and post-test results. The results of the pre-test and post-test show differences in average mean scores of 28.51 to 42.46. This finding shows that the Bar Model method was effective for the pupils that can improve pupils understanding in order to answer HOTS problem solving questions.
\end{abstract}

Keywords: Bar Model, Higher Order Thinking Skills (HOTs), Problem Solving, Mathematics

\section{Introduction}

Malaysia Education Blueprint 2013-2025 sets thinking skills as one of the six key features of student aspirations that a student needs to compete globally (Ministry of Education Malaysia, 2013). Pupils are challenged with Higher Order Thinking Skill (HOTs) questions in all subjects. Therefore, teachers are required to teach pupils science and mathematical concepts while improving their Higher Order Thinking Skills (HOTs) and reasoning skills as well (Kamaleswaran, 2017). As an educator it's our duty to deliver skills in various techniques and methods to improve the pupils understanding.

According to Rajendran (2017), many educators and researchers are currently focusing in teaching thinking skills. Many efforts have been made to incorporate thinking skills in many subjects including mathematics. Malaysia is in the process of achieving developed country status must be able to compete in international level, hence the thinking skills must be nurture and given priority.

The transformation of the curriculum outlined in Malaysian Education Blueprint 2013-2025 is a desire of the ministry which has to be implementing by educators. The ministry of education 
does believe that the catalyst of success of Malaysian Education Blueprint is mastery of higher order thinking skills by the teachers and pupils to the optimum by 2025 (MOE, 2013).

Many studies have been conducted in HOTs and problem solving particularly in mathematics because it is part of the curriculum for all the subject (Halim, 2015). Bar Model is developed from a set of generator series in rectangular form where its mathematical quantities consist of known and unknown quantities and their relationship to the problem is presented in real terms (Ho \& Lowrie, 2014). This visual clarity helps pupils to move towards making the right decisions in various contexts of mathematical problems. The intention of researcher in this is to use the Bar Model representative to convert word problem to visual so that pupils can see the problem clearly and solve it according to the problem need. Main intention of this study is to solve problem solving questions involving HOTs and to see the effectiveness for year 4 pupils.

\section{Problem Statements}

According to Siti \& Faridah (2015), problem solving is a very important skill for students in understanding the curriculum. It can be said that all learning topics in mathematics subjects at primary level are tested with problem solving skills as well as HOTs based questions. Kids need to learn skills to solve this type of question in order to achieve the learning objective as well.

Rajendran (2017) state that individuals can be trained to master thinking skills by providing systematic and continuous training. In other word, HOTs can be trained among pupils through a well-planned method. This can be achieved through a cognitive learning by associating new learning with existing schemes in pupils. Learning by memorizing without proper understanding does not help in learning for long term and in real live so much.

Therefore, the teaching style of teachers in implementing HOTs for Mathematics is very important to train pupils to think in higher order. Salwani (2014) said that the ability to understand what is learned is the key to the success of the mathematical learning process. This clearly shows pupils understanding are very important in the learning process. An innovative way or technique is essential in mathematics teaching and learning in order to encourage pupils to learn and apply HOTs effectively. Visual plays a very important role in order to enable pupils to understand problem solving questions involving HOTs better and in deep (Azrul, 2017). Bar Model is a problem solving strategy using visualisation which will encourage pupis to learn effectively

\section{Research Objective}

The main objective of this study is to find out the effectiveness of Bar Model method in solving problem solving questions involving HOTs for Year 4 pupils in SK Bukit Bandaraya.

\section{Research Methodology}

This study carried out to identify the effectiveness of bar model to solve HOTS questions for students in year 4 class in SK Bukit Bandaraya, Bangsar, Kuala Lumpur. This experimental research done through pre test and post test without control group was carried out to see the effectiveness 
of the Bar Model to solve HOTs questions in mathematic problem solving questions. There are six HOTs questions in the pre test and post test. The pre test need to be answered by the students before the Workshop and the post test is after the Workshop ends. The findings of the pre test and post test were analysed by using SPSS software version 22 to see the differences between the pre test and post tests results, the average changes and the average percentage changes. Therefore, T-test was used to analyze the data.

\section{Finding \& Discussion}

Table 1 shows the findings been analyzed by using SPSS version 22 for pre and post test results. The results of the pre and post show differences in average mean scores of 28.51 to 42.46 . Indicates the number of pupils involved in this study, which were 37 pupils from year 4 class. This finding shows that the Bar Model method was effective for the students.

\section{Table 1. One Sample T-Test}

\begin{tabular}{|l|l|l|l|l|}
\hline Type of Test & N & Mean & $\begin{array}{l}\text { Standard } \\
\text { deviation }\end{array}$ & T-value \\
\hline Pre Test & 37 & 28.5135 & 9.938 & 17.453 \\
\hline Post Test & 37 & 42.4595 & 14.303 & 18.057 \\
\hline $\mathrm{P}=0$ &
\end{tabular}

From the result of pre test and post test, the researcher found that by using bar model, the pupils pay more attention in the topic discussed. Visual representative show a clear picture of the problem and a clear understanding for the pupils. Pupils can answer the questions according to the questions need correctly by using bar model.

\section{Conclusion}

As a conclusion, Bar Model representative for HOTS questions affect pupils achievements. Pupils can convert problem questions to bar representatives and this gives a clear picture to the student to find the best solution for the questions. This visual representative helps pupils to solve HOTs problem solving question in Mathematics.

\section{Acknowledgement}

This research is a part of pilot test for researcher in order to complete his PhD. This research was supported by Prof. Dr. Marzita Puteh from Faculty of Science \& Mathematics, Universiti Pendidikan Sultan Idris, Tanjung Malim, Perak by giving guidance also comments to improve and complete this paper successfully. 
INTERNATIONAL JOURNAL OF ACADEMIC RESEARCH IN PROGRESSIVE EDUCATION AND DEVELOPMENT

Vol. 8, No. 2, 2019, E-ISSN: 2226-6348 @ 2019 HRMARS

\section{References}

Ho, S. Y., \& Lowrie, T. (2014). The model method: Students' performance and its effectiveness. Journal of Mathematical Behavior, 35, 87-100.

Hoven, J., \& Garelick, B. (2007). Singapore math: Simple or complex Educational Leadership, 65, 28-31.impact of the implementation of thinking skills approaches on pupils, in Research in Education Library, London: EPPI-Centre, Social Science.

Kamaleswaran, J. (2017) the development of a year five children engineering teaching module for hots um 2017

Ministry of Education (2013). 11 Anjakan yang Terkandung dalam Pelan Pembangunan Pendidikan 2013-2025, 1-25.

Ministry of Education Malaysia (MOE), Laporan Awal Pelan Pembangunan Pendidikan Malaysia 2013-2025, Putrajaya: Ministry of Education Malaysia

Ministry of Education. (2015). Executive Summary Malaysia Education Blueprint 2013-2025

(Preschool to Post-Secondary Education). [online] Available at: http://www.moe.gov.my/cms/upload_files/articlefile/2013/articlefile_file_003114.pdf [Accessed 2 Aug. 2015].

Awang, T. S. (2014). Pembangunan dan kesan pengintegrasian MAPLE dalam pengajaran Kalkulus Kamiran Terhadap Kefahaman Konseptual, Prosedural dan kesedaran meta kognitif. Tesis PhD. UKM 